\title{
A model of complaint based for overcrowding emergency department: Five-Level Hacettepe Emergency Triage System
}

\author{
Aşırı kalabalık aciller için şikayet temelli bir model: \\ Beş-Düzeyli Hacettepe Acil Triyaj Sistemi
}

\author{
Doğaç Niyazi ÖZÜÇELIK, ${ }^{1}$ Mehmet Mahir KUNT, ${ }^{1}$ Mehmet Ali KARACA, ${ }^{1}$ \\ Bülent ERBİL, ${ }^{1}$ Bülent SIVRİ, ${ }^{1}$ Ahmet ŞAHIN,${ }^{1}$ Yeşim ÇETINKAYA ŞARDAN, ${ }^{1}$ \\ Mehmet Mahir ÖZMEN, ${ }^{1}$ Bahar GÜÇIZ DOĞAN ${ }^{2}$
}

\section{BACKGROUND}

To compare ESI Five-Level Triage System with 5-Level Hacettepe Emergency Triage System (HETS), which was developed for Overcrowded EDs in our country.

\section{METHODS}

Over a period of six days, patients were assessed by a different ED staff everyday using HETS, then re-evaluated blindly by an emergency physician using HETS. Then patients were evaluated blindly for a third time by an independent, ESI-using emergency physician.

\section{RESULTS}

Of the patients in the study, 133 were men, 175 were women and the average age was $44.41 \pm 18.033$. Inter-rater agreement was $97.40 \%(\mathrm{Kappa}=0.963)$ between HETS and HETS-Blind, 74.35\% (Kappa=0.646) between HETS and ESI-Blind, 74.67\% (Kappa=0.652) between HETSBlind and ESI-Blind. Inter-observer agreement between the second emergency physician performing HETS-Blind and the first emergency physician, resident, or nurse was very good $(\mathrm{Kappa}=1.0)$. Intern doctor, non-medical secretary and paramedic were found to have almost very good agreement (Kappa $=0.971 ; 0.935 ; 0.864$, respectively). An overtriage of $7.25 \%$ and undertriage of $1.08 \%$ were found in HETS.

\section{CONCLUSION}

Complaint-based HEST developed for overcrowded EDs is a triage system with a very good agreement between observations and observers. low undertriage and overtriage ratios, and easy application by all staff from a non-medical secretary to the emergency physician.

Key Words: Complaint-based triage system; emergency medicinedepartment; emergency severity index; Hacettepe emergency triage system; triage.

\section{$\boldsymbol{A M A C}$}

Ülkemizdeki kalabalık aciller için geliştirdiğimiz şikayet temelli 5-düzeyli Hacettepe Acil Triyaj Sistemi'ni (HATS) ESI 5-düzeyli triyaj sistemiyle karşılaştırmaktır.

\section{GEREÇ VE YÖNTEM}

Altı gün süresince hergün başka bir görevli tarafından HATS ile değerlendirilen hastalar, bir acil tıp uzmanı tarafindan HATS ile kör olarak tekrar değerlendirildiler. Her iki değerlendirme kararını bilmeyen ve ESI konusunda uzman olan başka bir acil tıp uzmanı tarafından bağımsız ve kör olarak ESI ile değerlendirildiler.

\section{BULGULAR}

Araştırmadaki 308 hastanın 133'ü erkek, 175'i kadın ve yaş ortalaması 44,41 $\pm 18,033$ bulundu. HATS ile HATS-Kör karşılaştırıldığında gözlemler arası tutarlılık \%97,40 (Kappa=0,963), ESI-Kör ile karşılaştırıldığında gözlemler arası tutarl111k \%74,35 (Kappa=0,646) saptand1. HATS-Kör ile ESI-Kör karşılaştırıldığında gözlemler arası tutarlılık \%74,67 (Kappa=0,652) saptand1. Birinci acil tıp uzmanı, acil tıp asistanı ve acil hemşiresi ile HATS-Kör uygulayan ikinci acil tıp uzmanı arasındaki tutarlılığın en yüksek olduğu $(\mathrm{Kappa}=1,0)$, intern doktor, tıbbi olmayan acil sekreteri ve paramedikin de çok iyi olduğu (sırasıyla, Kappa $=0,971 ; 0,935 ; 0,864$ ) saptandı. HATS ile değerlendirilen hastalarda \%7,25 yanlış yüksek triyaj, \%1,08 yanlış düşük triyaj bulundu.

\section{SONUÇ}

Aşırı kalabalık acil servisler için geliştirilmiş olan şikayet temelli HATS, gözlemler ve gözlemciler arası tutarlığı yüksek, yanlış triyaj oranları düşük, tıbbi olmayan sekreterden acil tıp uzmanına kadar herkesin kolaylıkla uygulayabileceği bir triyaj sistemidir.

Anahtar Sözcükler: şikayet temelli triaj sistem; acil servis; acil tıp; acil şiddet indeksi; Hacettepe acil triyaj sistemi; triyaj. ${ }^{2}$ Halk Sağlı̆̆ı Anabilim Dalı, Ankara. 
Overcrowded emergency departments, dedicated to providing a continuous medical service 24 hours per day, 7 days per week, are becoming an ever-increasing problem in developing countries, such as Turkey, in terms of emergency medical services.

Different strategies of administration and triage have been developed to notice urgent and critical patients in overcrowded emergency departments and not to cause an increased rate of morbidity and mortality. ${ }^{[1-9]}$

Inappropriate care areas and long durations for care in overcrowded emergency departments cause problems between patients and health care providers. ${ }^{[10-14]}$

Different triage systems (2-Level, 3-Level, 4-Level and 5-Level) have been applied to determine the priority and management of health care for emergent patients in emergency departments. ${ }^{[15-19]}$

A survey carried out in US in 4897 hospitals showed that there is no triage system in $0.7 \%$ of emergency departments, a 2-level triage system in $0.3 \%$, a 3 -level triage system in $25.2 \%$, a 4-level triage system in $9.6 \%$, a 5-level ESI triage system in $56.9 \%$, another 5-level triage system in $6.3 \%$, and other triage system in $0.1 \%$ of emergency departments. ${ }^{[20]}$

It was also shown that the triage level application has changed according to the number of incoming patients; while 5-level ESI triage system applied in $78.3 \%$ of crowded emergency departments having more than 100.000 or more annual urgent patients, 3 -level triage system has been applied in $60.2 \%$ of the emergency departments having less than 1.000 annual urgent patients..$^{[20,21]}$

As suggested in the statement published in 2009 by the Ministry of Health of Turkish Government, the 3-level triage system has been commonly used in Turkey. In 3-level triage system, patients are categorized as emergent (red), urgent (yellow) and non-urgent (green). ${ }^{[22]}$

5-level triage systems such as Australasian or National Triage Scale (ATS-NTS), Canadian Triage and Acuity Scale (CTAS), Manchester Triage System (MTS), and the Emergency Severity Index (ESI) have been widely used in emergency departments of developed countries in terms of emergency medical services. ${ }^{[23-28]}$

Validity and reliability of 5-level triage system were found to be greater than 3-level systems. ${ }^{[15,29-31]}$

There are various studies about accuracy, reliability and validity of acute patient triage in ATS-NTS, MTS, CTAS and ESI 5-level systems. ${ }^{[21,32-37]}$

ESI 5-level triage system which is widely used and has high value in US has been developed by emergency physicians, Richard Wuerz and David Eitel. In this system, patients are categorized from triage level 1-2 (life-threatening and critical conditions) to triage level 3-5 (diseases according to the necessities for expected sources usage). ${ }^{[38,39]}$

With respect to the characteristics of the hospitals, the triage mission is accomplished by different health care providers such as the emergency physicians, nurses or paramedics in emergency departments. Studies about which of these health workers perform more accurate triage are insufficient. ${ }^{[40-45]}$

Although ESI 5-level triage system has higher reliability and validity, it is unlikely to be routinely applied in the emergency departments of our country since it requires experience and education and, it is difficult to find a triage expert. Evaluation time is long in triage area and violent actions are made by patients who do not tolerate waits in overcrowded emergency departments (1.000 or more patients/day).

For overcrowded emergency departments, an emergency triage system is needed that can be applied quickly, does not require any education or experience and is determined based on the priority for care according to the chief complaints, prediagnosis or symptoms of the patients.

To address this need, a complaint-based 5-level Hacettepe Emergency Triage System (HETS) has been developed for overcrowded emergency departments in our country.

The aim of this study is to compare ESI 5-level triage system which has been tested for its world-wide validity and reliability and HETS 5-level triage system and to test its consistency and validity for emergency triage applications.

\section{MATERIALS AND METHODS}

This methodological study was carried out with 308 patients in the emergency department of Hacettepe University Faculty of Medicine, which had an annual patient number of approximately 35.000 between $08 / 08 / 2008$ and $08 / 15 / 2008$. The study was approved by the Ethical Committee.

In the first stage of the study, 5-level triage systems were examined and evaluated.

Secondly, patient triage application complaints from the Emergency Department of Medical Faculty of Hacettepe University over a one-year period were collected and evaluated.

Third, 120 chief complaints, which were mostly applied reasons, were sorted into 5 triage levels according to the priority of the condition. These complaints were then listed alphabetically according to triage levels determined by the users. If there is a condition with a new complaint not written in algorithm, 


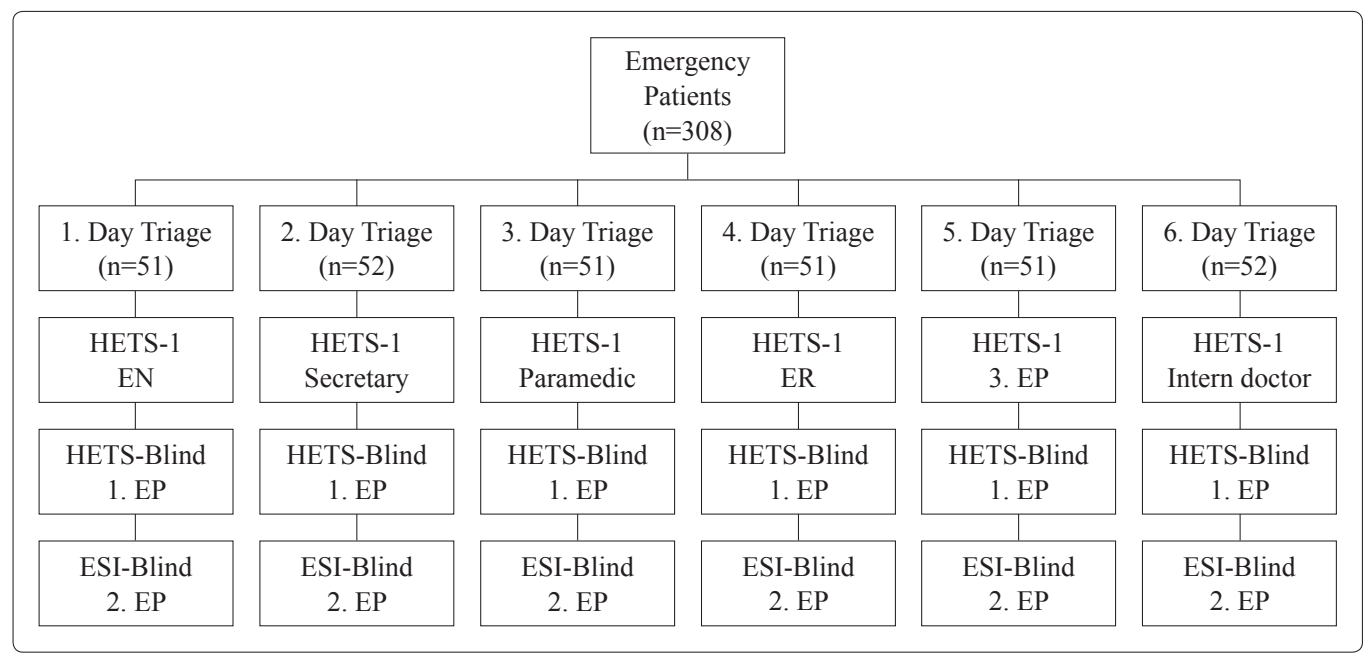

Fig. 1. The study diagram of HATS study. HETS: Hacettepe Emergency Triage System; ESI: Emergency Severity Index; EN: Emergency Nurse; EP: Emergency Physician; ER: Emergency Resident.

'Ask to Doctor' is written on the last line of every triage levels of complaint category.

"Hacettepe Emergency Triage System (HETS)" cards with columns listing the complaint with triage levels of the patients (T1: Critical-Red, T2: EmergentOrange, T3: Urgent-Yellow, T4: Less Urgent-Green, T5: Non Urgent-Blue), evaluation time (T1: 0 minute, T2: 5-15 min, T3: 30-60 min, T4: 1-2 hours, T5: 3-4 hours) and re-evaluation time (T1: Always, T2: In every $15 \mathrm{~min}, \mathrm{~T} 3$ : Once in $60 \mathrm{~min}, \mathrm{~T} 4$ : Once in $60 \mathrm{~min}$, T5: Once in $120 \mathrm{~min}$ ) were hung on the triage table.

In the fourth stage, patients arriving at the Emergency Department were evaluated between 8:00 and
18:00 over a period of six days by different Emergency Department staff (non-medical emergency secretary, emergency nurse, paramedic, emergency intern doctor-last medical student, emergency resident and emergency physician) according to HETS (recorded as HETS-1) (Figure 1).

Patients were also evaluated by an emergency physician who did not know the decision of the first triage staff (the same person over six days) again according to HETS (recorded as HETS-blind).

After the patient's triage levels, care areas and priorities treatment were determined, an emergency physician who did not know the previous two decisions

Table 1. Vitals signs and demographical information of patients in triage

\begin{tabular}{|c|c|c|c|c|c|c|c|}
\hline & $(\mathrm{N}=308)$ & $\begin{array}{l}\text { Nurse } \\
(n=51)\end{array}$ & $\begin{array}{l}\text { Secretary } \\
(n=52)\end{array}$ & $\begin{array}{l}\text { Paramedic } \\
(n=51)\end{array}$ & $\begin{array}{c}\text { ER } \\
(n=51)\end{array}$ & $\begin{array}{c}\text { EP } \\
(n=51)\end{array}$ & $\begin{array}{l}\text { Intern } \\
(n=52)\end{array}$ \\
\hline \multirow[t]{2}{*}{ Gender } & Male $=133$ & Male $=16$ & Male $=21$ & Male $=21$ & Male $=25$ & Male $=22$ & Male $=27$ \\
\hline & Female $=175$ & Female $=35$ & Female $=31$ & Female $=30$ & Female $=25$ & Female $=29$ & Female $=25$ \\
\hline Age (Mean. \pm SD) & $44.41 \pm 18.03$ & $44.98 \pm 18.20$ & $42.90 \pm 19.44$ & $44.00 \pm 18.30$ & $46.61 \pm 16.22$ & $47.35 \pm 18.00$ & $40.67 \pm 17.88$ \\
\hline Min/Max & $16 / 84$ & $18 / 78$ & $16 / 82$ & $17 / 84$ & $17 / 83$ & $18 / 80$ & $20 / 82$ \\
\hline SBP $($ Mean. \pm SD $)$ & $115.5 \pm 22.43$ & $119.61 \pm 17.34$ & $115.77 \pm 19.73$ & $116.86 \pm 21.60$ & $116.47 \pm 25.83$ & $114.92 \pm 28.79$ & $109.62 \pm 19.09$ \\
\hline Min/Max & $0 / 220$ & $80 / 155$ & $80 / 200$ & $80 / 180$ & $0 / 180$ & $80 / 220$ & $60 / 175$ \\
\hline DBP (Mean. \pm SD) & $72.6 \pm 12.99$ & $75 \pm 11.24$ & $75.10 \pm 12.81$ & $71.18 \pm 11.68$ & $73.53 \pm 15.20$ & $70.63 \pm 14.18$ & $70.19 \pm 12.08$ \\
\hline $\operatorname{Min} / \operatorname{Max}$ & $0 / 110$ & $50 / 101$ & $50 / 110$ & $45 / 90$ & $0 / 100$ & $50 / 110$ & $40 / 100$ \\
\hline Puls (Mean. \pm SD) & $88.6 \pm 16.62$ & $90.9 \pm 16.21$ & $88.52 \pm 16.81$ & $85.53 \pm 15.17$ & $87.96 \pm 20.78$ & $89.51 \pm 15.79$ & $89.19 \pm 14.61$ \\
\hline Min/Max & $0 / 162$ & $60 / 145$ & $56 / 140$ & $58 / 130$ & $0 / 162$ & $55 / 137$ & $56 / 132$ \\
\hline RR (Mean. \pm SD) & $17.3 \pm 3.27$ & $19.59 \pm 3.10$ & $17.73 \pm 1.75$ & $17.04 \pm 1.87$ & $17.18 \pm 4.20$ & $16.71 \pm 4.53$ & $15.54 \pm 1.40$ \\
\hline Minn/Max & $0 / 36$ & $16 / 34$ & $15 / 24$ & $14 / 22$ & $0 / 28$ & $12 / 36$ & $14 / 20$ \\
\hline PO (Mean. \pm SD) & $96.2 \pm 6.37$ & $95.57 \pm 4.83$ & $96.60 \pm 2.80$ & $96.61 \pm 1.88$ & $95.37 \pm 13.69$ & $96.22 \pm 3.92$ & $96.81 \pm 3.08$ \\
\hline $\operatorname{Min} / \operatorname{Max}$ & $0 / 99$ & 75/99 & $80 / 99$ & $87 / 99$ & 0/99 & $75 / 99$ & $77 / 99$ \\
\hline Fever (Mean. \pm SD) & $36.49 \pm 21.16$ & $36.55 \pm 0.61$ & $36.55 \pm 0.63$ & $36.76 \pm 0.61$ & $35.88 \pm 5.16$ & $36.51 \pm 0.14$ & $36.66 \pm 0.60$ \\
\hline $\operatorname{Min} / \operatorname{Max}$ & $0 / 39.6$ & $35.8 / 38.9$ & $35.8 / 39.6$ & $35.9 / 39.6$ & 0/38.9 & $35.8 / 38.1$ & $35.7 / 38.8$ \\
\hline
\end{tabular}

SD: Standart deviation; Min: Minimum; Max: Maximum; SBP: Systolic blood pressure; DBP: Diastolic blood pressure; RR: Respiratory rate; PO: Pulse oximetry. 
Table 2. Comparison between HETS-1, HETS-Blind and ESI-Blind in all patients

\begin{tabular}{|c|c|c|c|c|c|c|c|c|c|c|c|c|}
\hline \multirow[t]{2}{*}{ Triage system } & \multicolumn{6}{|c|}{ HETS-Blind } & \multicolumn{6}{|c|}{ ESI-Blind } \\
\hline & $\mathrm{T} 1$ & $\mathrm{~T} 2$ & $\mathrm{~T} 3$ & $\mathrm{~T} 4$ & T5 & $\mathrm{n}$ & $\mathrm{T} 1$ & $\mathrm{~T} 2$ & T3 & $\mathrm{T} 4$ & T5 & $\mathrm{n}$ \\
\hline \multicolumn{13}{|l|}{ HETS-1 } \\
\hline $\mathrm{T} 1$ & 24 & 1 & - & - & - & 25 & 1 & 22 & 2 & - & - & 25 \\
\hline $\mathrm{T} 2$ & 1 & 44 & - & - & - & 45 & - & 25 & 19 & 1 & - & 45 \\
\hline T3 & - & 3 & 136 & - & - & 139 & - & 6 & 127 & 6 & - & 139 \\
\hline $\mathrm{T} 4$ & - & - & 2 & 82 & - & 84 & - & 1 & 4 & 65 & 14 & 84 \\
\hline T5 & - & - & - & 1 & 14 & 15 & - & - & - & 4 & 11 & 15 \\
\hline $\mathrm{n}$ & 25 & 48 & 138 & 83 & 14 & 308 & 1 & 54 & 152 & 76 & 25 & 308 \\
\hline & \multicolumn{6}{|c|}{ Kappa $=0.963$} & \multicolumn{6}{|c|}{ Карра $=0.646$} \\
\hline & \multicolumn{6}{|c|}{ Agreement $=97.40 \%$} & \multicolumn{6}{|c|}{ Agreement $=74.35 \%$} \\
\hline
\end{tabular}

HETS: Hacettepe Emergency Triage System; ESI: Emergency Severity Index.

and specialized in ESI independently and blindly reevaluated the patients (the same person over six days).

Triage and demographical information of patients evaluated as HETS-1, HETS-blind and independent ESI were statistically analyzed with SPSS program for Windows. Inter- and intra-observer agreement was calculated by Kappa statistics.

\section{RESULTS}

Of the patients in the study, 133 were men, 175 were women and the average age was $44.41 \pm 18.33$ years old $($ median $=44$, minimum $=16$, maximum $=84$ ).

The numbers and vitals of patients in the study were found to be randomly close to each other (Table 1).

When 308 patients were evaluated by six different emergency department staff with HETS-1 and reevaluated blindly by the first emergency physician according to HETS (HETS-blind), agreement between triage decisions was $97.40 \%$ in all triage levels (Kap$\mathrm{pa}=0.963$ ).

According to triage levels, T1 sensitivity was $96 \%$ and specificity was $99.64 \%$; T2 sensitivity was $91.66 \%$ and specificity was $99.61 \%$; T3 sensitivity was $98.55 \%$ and specificity was $98.23 \%$; T4 sensitivity was $98.79 \%$ and specificity was $99.11 \%$; and T5 sensitivity was $100 \%$ and specificity was $99.65 \%$ (Table 2).

When 308 patients were evaluated by six different emergency department staff with HETS-1 and reevaluated blindly by the second emergency physician according to ESI, agreement between triage decisions was $74.35 \%$ in all triage levels (Kappa $=0.646$ ).

According to triage levels, T1 sensitivity was $100 \%$ and specificity was $92.18 \%$; T2 sensitivity was $46.29 \%$ and specificity was $92.12 \%$; T3 sensitivity was $83.55 \%$ and specificity was $92.30 \%$; T4 sensitivity was $85.52 \%$ and specificity was $91.81 \%$; and
T5 sensitivity was $44 \%$ and specificity was $98.58 \%$ (Table 2).

When 308 patients were evaluated by the first emergency physician according to HETS (HETS-blind) and re-evaluated blindly by second emergency physician according to ESI, agreement between triage decisions was $74.67 \%$ in all triage levels (Kappa=0.652).

According to triage levels, T1 sensitivity was $100 \%$ and specificity was $92.18 \%$; T2 sensitivity was $51.85 \%$ and specificity was $93.30 \%$; T3 sensitivity was $83.55 \%$ and specificity was $92.94 \%$; T4 sensitivity was $84.21 \%$ and specificity was $91.81 \%$; and T5 sensitivity was $40 \%$ and specificity was $98.58 \%$ (Table 3).

When 51 patients were evaluated by the emergency nurse according to HETS (HETS-1) and re-evaluated blindly by the first emergency physician according to HETS on the first day, agreement between triage decisions was $100 \%$ in all triage levels $(\mathrm{Kappa}=1.0)$. When these same patients were re-evaluated blindly

Table 3. Comparison between HETS-1 and ESI-Blind in all patients

\begin{tabular}{ccccccc}
\hline Triage system & \multicolumn{7}{c}{ ESI-Blind } \\
\cline { 2 - 7 } & T1 & T2 & T3 & T4 & T5 & n \\
\hline HETS-Blind & 1 & 21 & 3 & - & - & 25 \\
T1 & - & 28 & 19 & 1 & - & 45 \\
T2 & - & 4 & 127 & 7 & - & 138 \\
T3 & - & 1 & 3 & 64 & 15 & 83 \\
T4 & - & - & - & 4 & 10 & 14 \\
T5 & 1 & 54 & 152 & 76 & 25 & 308 \\
n & \multicolumn{7}{c}{ Kappa $=0.652$} \\
& Agreement=74.67\% \\
\hline
\end{tabular}

HETS: Hacettepe Emergency Triage System; ESI: Emergency Severity Index. 
by the second emergency physician according to ESI on the second day, agreement between triage decisions was $78.43 \%$ in all triage levels. The evaluations by the first emergency physician according to HETS (HETSblind) and the second emergency physician according to ESI on the first day, had $78.43 \%$ agreement between triage decisions in all triage levels (Table 4).

When 52 patients were evaluated by the non-medical emergency secretary according to HETS (HETS-1) and re-evaluated blindly by the first emergency physician according to HETS on the second day, agreement between triage decisions was $96.15 \%$ in all triage levels $(\mathrm{Kappa}=0.935)$. When these same patients were reevaluated blindly by the second emergency physician according to ESI on the second day, agreement between triage decisions was $82.69 \%$ in all triage levels. The evaluations by the first emergency physician according to HETS (HETS-blind) and the second emergency physician according to ESI had $86.53 \%$ agreement between triage decisions in all triage levels (Table 5).

When 51 patients were evaluated by the paramedic according to HETS (HETS-1) and re-evaluated blindly by the first emergency physician according to HETS on the third day, agreement between triage decisions was $90.19 \%$ in all triage levels (Kappa $=0.864$ ). When these same patients were re-evaluated blindly by the second emergency physician according to HETS on the third day, agreement between triage decisions was $66.66 \%$ in all triage levels. The evaluations by the first emergency physician according to HETS (HETSblind) and the second emergency physician according to ESI had $66.66 \%$ agreement between triage decisions in all triage levels (Table 6).

When 51 patients were evaluated by the emergency resident according to HETS (HETS-1) and re-evaluated blindly by the first emergency physician according

Table 4. Comparison between HETS-Blind and ESI-Blind in patients evaluated by the emergency nurse

\begin{tabular}{|c|c|c|c|c|c|c|c|c|c|c|c|c|}
\hline \multirow[t]{2}{*}{ Nurse triage } & \multicolumn{6}{|c|}{ HETS-Blind } & \multicolumn{6}{|c|}{ ESI-Blind } \\
\hline & $\mathrm{T} 1$ & $\mathrm{~T} 2$ & $\mathrm{~T} 3$ & $\mathrm{~T} 4$ & T5 & $\mathrm{n}$ & $\mathrm{T} 1$ & $\mathrm{~T} 2$ & $\mathrm{~T} 3$ & $\mathrm{~T} 4$ & $\mathrm{~T} 5$ & $\mathrm{n}$ \\
\hline \multicolumn{13}{|l|}{ HETS-1 } \\
\hline $\mathrm{T} 1$ & 7 & - & - & - & - & 7 & - & 7 & - & - & - & 7 \\
\hline $\mathrm{T} 2$ & - & 7 & - & - & - & 7 & - & 6 & 1 & - & - & 7 \\
\hline T3 & - & - & 25 & - & - & 25 & - & - & 24 & 1 & - & 25 \\
\hline $\mathrm{T} 4$ & - & - & - & 10 & - & 10 & - & - & - & 8 & 2 & 10 \\
\hline T5 & - & - & - & - & 2 & 2 & - & - & - & - & 2 & 2 \\
\hline \multirow[t]{3}{*}{$\mathrm{n}$} & 7 & 7 & 25 & 10 & 2 & 51 & - & 13 & 25 & 9 & 4 & 51 \\
\hline & \multicolumn{6}{|c|}{ Kappa $=1.000$} & \multicolumn{6}{|c|}{$\begin{array}{l}\text { Kappa could not calculated } \\
\text { because of } \mathrm{T} 1 \text { column is empty }\end{array}$} \\
\hline & \multicolumn{6}{|c|}{ Agreement $=100 \%$} & \multicolumn{6}{|c|}{ Agrrement $=78.43 \%$} \\
\hline
\end{tabular}

HETS: Hacettepe Emergency Triage System; ESI: Emergency Severity Index.

Table 5. Comparison between HETS-Blind and ESI-Blind in patients evaluated by the non-medical secretary

\begin{tabular}{|c|c|c|c|c|c|c|c|c|c|c|c|c|}
\hline \multirow[t]{2}{*}{ Sekretary triage } & \multicolumn{6}{|c|}{ HETS-Blind } & \multicolumn{6}{|c|}{ ESI-Blind } \\
\hline & $\mathrm{T} 1$ & $\mathrm{~T} 2$ & T3 & $\mathrm{T} 4$ & T5 & $\mathrm{n}$ & $\mathrm{T} 1$ & $\mathrm{~T} 2$ & T3 & T4 & T5 & $\mathrm{n}$ \\
\hline \multicolumn{13}{|l|}{ HETS-1 } \\
\hline $\mathrm{T} 1$ & 2 & 1 & - & - & - & 3 & - & 3 & - & - & - & 3 \\
\hline $\mathrm{T} 2$ & - & 3 & - & - & - & 3 & - & 2 & 1 & - & - & 3 \\
\hline $\mathrm{T} 3$ & - & 1 & 30 & - & - & 31 & - & 1 & 29 & 1 & - & 31 \\
\hline $\mathrm{T} 4$ & - & - & - & 12 & - & 12 & - & - & - & 10 & 2 & 12 \\
\hline T5 & - & - & - & - & 3 & 3 & - & - & - & 1 & 2 & 3 \\
\hline \multirow{3}{*}{$\mathrm{n}$} & 2 & 5 & 30 & 12 & 3 & 52 & - & 6 & 30 & 12 & 4 & 52 \\
\hline & \multicolumn{6}{|c|}{ Kappa $=0.935$} & \multicolumn{6}{|c|}{$\begin{array}{c}\text { Kappa could not calculated } \\
\text { because of } \mathrm{T} 1 \text { column is empty }\end{array}$} \\
\hline & \multicolumn{6}{|c|}{ Agreement $=96.15 \%$} & \multicolumn{6}{|c|}{ Agreement $=82.69 \%$} \\
\hline
\end{tabular}

HETS: Hacettepe Emergency Triage System; ESI: Emergency Severity Index. 
Table 6. Comparison between HETS-Blind and ESI-Blind in patients evaluated by the paramedic

\begin{tabular}{|c|c|c|c|c|c|c|c|c|c|c|c|c|}
\hline \multirow[t]{2}{*}{ Paramedic triage } & \multicolumn{6}{|c|}{ HETS-Blind } & \multicolumn{6}{|c|}{ ESI-Blind } \\
\hline & $\mathrm{T} 1$ & $\mathrm{~T} 2$ & $\mathrm{~T} 3$ & $\mathrm{~T} 4$ & T5 & $\mathrm{n}$ & $\mathrm{T} 1$ & $\mathrm{~T} 2$ & $\mathrm{~T} 3$ & $\mathrm{~T} 4$ & T5 & $\mathrm{n}$ \\
\hline \multicolumn{13}{|l|}{ HETS-1 } \\
\hline $\mathrm{T} 1$ & 3 & - & - & - & - & 3 & - & 3 & - & - & - & 3 \\
\hline $\mathrm{T} 2$ & 1 & 9 & - & - & - & 10 & - & 4 & 6 & - & - & 10 \\
\hline $\mathrm{T} 3$ & - & 2 & 17 & - & - & 19 & - & 3 & 15 & 1 & - & 19 \\
\hline $\mathrm{T} 4$ & - & - & 1 & 15 & - & 16 & - & - & 2 & 13 & 1 & 16 \\
\hline T5 & - & - & - & 1 & 2 & 3 & - & - & - & 1 & 2 & 3 \\
\hline \multirow[t]{3}{*}{$\mathrm{n}$} & 4 & 11 & 18 & 16 & 2 & 51 & - & 10 & 23 & 15 & 3 & 51 \\
\hline & \multicolumn{6}{|c|}{ Карра $=0.864$} & \multirow{2}{*}{\multicolumn{6}{|c|}{$\begin{array}{l}\text { Kappa could not calculated } \\
\text { because of } \mathrm{T} 1 \text { column is empty } \\
\text { Agreement }=66.66 \%\end{array}$}} \\
\hline & & & eeme & $=90$ & $19 \%$ & & & & & & & \\
\hline
\end{tabular}

HETS: Hacettepe Emergency Triage System; ESI: Emergency Severity Index.

Table 7. Comparison between HETS-Blind and ESI-Blind in patients evaluated by the emergency resident

\begin{tabular}{|c|c|c|c|c|c|c|c|c|c|c|c|c|}
\hline \multirow[t]{2}{*}{ Resident triage } & \multicolumn{6}{|c|}{ HETS-Blind } & \multicolumn{6}{|c|}{ ESI-Blind } \\
\hline & $\mathrm{T} 1$ & $\mathrm{~T} 2$ & $\mathrm{~T} 3$ & T4 & $\mathrm{T} 5$ & $\mathrm{n}$ & $\mathrm{T} 1$ & $\mathrm{~T} 2$ & $\mathrm{~T} 3$ & $\mathrm{~T} 4$ & T5 & $\mathrm{n}$ \\
\hline \multicolumn{13}{|l|}{ HETS-1 } \\
\hline $\mathrm{T} 1$ & 4 & - & - & - & - & 4 & 1 & 3 & - & - & - & 4 \\
\hline $\mathrm{T} 2$ & - & 6 & - & - & - & 6 & - & 4 & 1 & 1 & - & 6 \\
\hline $\mathrm{T} 3$ & - & - & 20 & - & - & 20 & - & - & 20 & - & - & 20 \\
\hline T4 & - & - & - & 16 & - & 16 & - & - & - & 12 & 4 & 16 \\
\hline T5 & - & - & - & - & 5 & 5 & - & - & - & 1 & 4 & 5 \\
\hline \multirow[t]{3}{*}{$\mathrm{n}$} & 4 & 6 & 20 & 16 & 5 & 51 & 1 & 7 & 21 & 14 & 8 & 51 \\
\hline & \multicolumn{6}{|c|}{ Kappa $=1.000$} & \multirow{2}{*}{\multicolumn{6}{|c|}{$\begin{array}{c}\text { Kappa }=0.727 \\
\text { Areement }=8039 \%\end{array}$}} \\
\hline & \multicolumn{6}{|c|}{ Agreement $=100 \%$} & \multicolumn{5}{|c|}{ Agreement $=80.39 \%$} & \\
\hline
\end{tabular}

HETS: Hacettepe Emergency Triage System; ESI: Emergency Severity Index.

to HETS on the fourth day, agreement between triage decisions was $100 \%$ in all triage levels (Kappa $=1.0)$. When these same patients were re-evaluated blindly by the second emergency physician according to ESI on the fourth day, agreement between triage decisions was $80.39 \%$ in all triage levels (Kappa $=0.727$ ). The evaluations by the first emergency physician according to HETS (HETS-blind) and the second emergency physician according to ESI had $80.39 \%$ agreement between triage in all triage levels (Kappa $=0.727)($ Table 7).

When 51 patients were evaluated by the third emergency physician according to HETS (HETS-1) and reevaluated blindly by the first emergency physician according to HETS on the fifth day, agreement between triage decisions was determined as $100 \%$ in all triage levels (Kappa=1.0). When these same patients were re-evaluated blindly by the second emergency physician according to ESI on the fifth day, agreement between triage decisions was determined as $68.62 \%$ in all triage levels. The evaluations by the first emer- gency physician according to HETS (HETS-blind) and the second emergency physician according to ESI had $68.62 \%$ agreement between triage decisions in all triage levels (Table 8).

When 52 patients were evaluated by intern doctor according to HETS (HETS-1) and re-evaluated blindly by the first emergency physician according to HETS on the sixth day, agreement between triage decisions was determined as $98.07 \%$ in all triage levels (Kap$\mathrm{pa}=0.971)$. When these same patients were re-evaluated blindly by the second Emergency Physician according to ESI on the sixth day, agreement between triage decisions was determined as $78.84 \%$ in all triage levels. The evaluations by the first emergency physician according to HETS (HETS-blind) and the second emergency physician according to ESI had $76.92 \%$ agreement between triage decisions in all triage levels (Table 9).

Of all 308 patients evaluated by six different emergency triage staff as HETS-1, HETS-blind and ESI- 
Table 8. Comparison between HETS-Blind and ESI-Blind in patients evaluated by the emergency physician

\begin{tabular}{|c|c|c|c|c|c|c|c|c|c|c|c|c|}
\hline \multirow[t]{2}{*}{ Physician triage } & \multicolumn{6}{|c|}{ HETS-Blind } & \multicolumn{6}{|c|}{ ESI-Blind } \\
\hline & $\mathrm{T} 1$ & $\mathrm{~T} 2$ & T3 & $\mathrm{T} 4$ & T5 & $\mathrm{n}$ & $\mathrm{T} 1$ & $\mathrm{~T} 2$ & T3 & $\mathrm{T} 4$ & T5 & $\mathrm{n}$ \\
\hline \multicolumn{13}{|l|}{ HETS-1 } \\
\hline $\mathrm{T} 1$ & 3 & - & - & - & - & 3 & - & 2 & 1 & - & - & 3 \\
\hline $\mathrm{T} 2$ & - & 14 & - & - & - & 14 & - & 6 & 8 & - & - & 14 \\
\hline $\mathrm{T} 3$ & - & - & 19 & - & - & 19 & - & - & 16 & 3 & - & 19 \\
\hline $\mathrm{T} 4$ & - & - & - & 15 & - & 15 & - & - & - & 13 & 2 & 15 \\
\hline T5 & - & - & - & - & - & - & - & - & - & - & - & - \\
\hline \multirow[t]{3}{*}{$\mathrm{n}$} & 3 & 14 & 19 & 15 & - & 51 & - & 8 & 25 & 16 & 2 & 51 \\
\hline & \multicolumn{6}{|c|}{ Kappa $=1.000$} & \multirow{2}{*}{\multicolumn{6}{|c|}{$\begin{array}{l}\text { Kappa could not calculated } \\
\text { because of T } 1 \text { column is empty } \\
\text { Agreement }=68.62 \%\end{array}$}} \\
\hline & & & reeme & $t=10$ & & & & & & & & \\
\hline
\end{tabular}

HETS: Hacettepe Emergency Triage System; ESI: Emergency Severity Index.

Table 9. Comparison between HETS-Blind and ESI-Blind in patients evaluated by the intern doctor

\begin{tabular}{|c|c|c|c|c|c|c|c|c|c|c|c|c|}
\hline \multirow[t]{2}{*}{ Intern } & \multicolumn{6}{|c|}{ HETS-Blind } & \multicolumn{6}{|c|}{ ESI-Blind } \\
\hline & $\mathrm{T} 1$ & $\mathrm{~T} 2$ & T3 & $\mathrm{T} 4$ & T5 & $\mathrm{n}$ & $\mathrm{T} 1$ & $\mathrm{~T} 2$ & T3 & $\mathrm{T} 4$ & T5 & $\mathrm{n}$ \\
\hline \multicolumn{13}{|c|}{ HETS-1 } \\
\hline T1 & 5 & - & - & - & - & 5 & - & 4 & 1 & - & - & 5 \\
\hline $\mathrm{T} 2$ & - & 5 & - & - & - & 5 & - & 3 & 2 & - & - & 5 \\
\hline $\mathrm{T} 3$ & - & - & 25 & - & - & 25 & - & - & 25 & - & - & 25 \\
\hline $\mathrm{T} 4$ & - & - & 1 & 14 & - & 15 & - & - & 1 & 11 & 3 & 15 \\
\hline T5 & - & - & - & - & 2 & 2 & - & - & - & - & 2 & 2 \\
\hline \multirow[t]{3}{*}{$\mathrm{n}$} & 5 & 5 & 26 & 14 & 2 & 52 & - & 7 & 29 & 11 & 5 & 52 \\
\hline & \multicolumn{6}{|c|}{ Kappa $=0.971$} & \multirow{2}{*}{\multicolumn{6}{|c|}{$\begin{array}{c}\text { Kappa could not calculated } \\
\text { because of T1 column is empty } \\
\text { Agreement }=78.84 \%\end{array}$}} \\
\hline & & $\mathrm{Agr}$ & eemer & $t=98$. & $7 \%$ & & & & & & & \\
\hline
\end{tabular}

HETS: Hacettepe Emergency Triage System; ESI: Emergency Severity Index.

blind over six days, a total of $77(8.33 \%)$ showed an inconsistency with respect to their triage levels.

While HETS triage level in $12.98 \%$ of all patients was lower than the ESI triage level (incorrect undertriage), HETS triage level in $87.02 \%$ of all patients was higher than ESI triage level (incorrect overtriage).

Of the undertriaged, four patients were categorized in HETS T3 instead of ESI T2; three were HAT T4 instead of ESI T3; and three were HETS T5 instead of ESI T4. The greatest inconsistency at $31.16 \%$ was shown in Triage 1 . Twenty-two patients evaluated as Triage 1 according to HETS were evaluated as Triage 2 according to ESI.

\section{DISCUSSION}

Due to the problems that arise from overcrowded emergency departments, different emergency triage systems and solutions have been tested around the world, including in Turkey. ${ }^{[1-12]}$
Five-level triage systems have been commonly used in emergency departments of countries where emergency medical services have been developed. ${ }^{[23-28]}$

In the United States, ESI has emerged as a new triage system in which education and experience are needed; it is the most widely used and is the most valuable of emergency triage systems. ${ }^{[38,39]}$

There are different studies about the accuracy, reliability and validity of 5-level triage systems for the acute patient triage. ${ }^{[21,32-37]}$ In an observational study including 486 patients by Worster et al., ${ }^{[36]}$ there was no statistical difference between ESI and CTAS triage systems. In a study including 900 patients conducted by eight educated triage nurses, in which Storm-Versloot et al. ${ }^{[33]}$ used MTS and ESI without using a triage algorithm, it was reported that ESI had a lower triage score than MTS (11\% to $20 \%)$. In this study, all three systems were found to have a low sensitivity.

In a theoretical scenario study by Storm-Versloot et 
al., ${ }^{[46]}$ including comparison of MTS and ESI systems, inter-observer Kappa was found as 0.76 for MTS, 0.46 for ESI; intra-observation Kappa was found as 0.84 for MTS and as 0.65 for ESI.

In a study by Burström et al., ${ }^{[43]}$ a comparison between triages of physicians and nurses between 8:00 and 21:00 was made; the team led by the physician had a greater advantage than the others in terms of activity and quality indications.

In a study by Chi et al., ${ }^{[47]}$ including 3171 patients and comparing Taiwan Triage System (TTS) and ESI, ESI was found to be more accurate than TTS in terms of determining acute patients. When patients determined at 1-level Triage by TTS were evaluated by ESI, their ESI levels were found as ESI 1 in $21.1 \%$ of patients, as ESI 2 in $68.1 \%$, as ESI 3 in $7.4 \%$, as ESI 4 in $3.4 \%$ and as ESI 5 in $0 \%$. When patients determined at 3-level Triage by TTS were evaluated by ESI, their ESI levels were found as ESI 1 in $0.1 \%$ of them, as ESI 2 in $26.2 \%$, as ESI 3 in $39.5 \%$, as ESI 4 in $27.5 \%$ and as ESI 5 in $6.8 \% .{ }^{[47]}$

In a study by Durand et al., ${ }^{[41]}$ including evaluations of decisions distinguishing patients between urgent and not urgent by doctors and nurses in France, there was a high level of agreement between the two groups in terms of cranial injury, gynecologic and toxicologic indications while there was a low level of agreement between the two groups in terms of urinary system and hospitalization. Doctors had higher sensitivity ( $94 \%$ to $43.1 \%)$ and specificity ( $89.5 \%$ to $30.9 \%)$ than nurses in terms of hospitalization of urgent and non-urgent patients. ${ }^{[41]}$

In a study by Kahveci et al., ${ }^{[45]}$ comparing emergency residents and paramedics, there was agreement between two groups in $47 \%$ of 3 -level triage decisions $(\mathrm{Kappa}=0.47)$ and $45 \%$ of 5 -level ATS triage decisions (Kappa $=0.45)$.

Kahveci et al. ${ }^{[45]}$ emphasized that there has to be a new and simple triage scale that can be easily applied by uneducated personnel in all emergency services.

In a reliability study by Tanabe et al., ${ }^{[32]}$ including retroactive examination of triage records in terms of the triage accuracy of nurses who have taken ESI education, a better consistency between nurses was found (Kappa=0.89). In a study by Buschhorn et al. ${ }^{[48]}$ examining the reliability of ESI among EMS personnel, the level of agreement between EMS personnel and emergency triage nurses was found to be medium $(\mathrm{Kappa}=0.409)$. In a randomized controlled study by Worster et al., ${ }^{[37]}$ comparing 5-level ESI and CTAS triage, there was no difference between triage nurses applying ESI and CTAS (Kappa=0.91, Kappa=0.89).

In our study, HETS was found to have high level of agreement when applied by different observers and compared to a different triage system.

In our study, when all patients evaluated by emergency department staff using HETS were re-evaluated blindly using HETS, there was a $97.40 \%$ agreement between observations (Kappa value was 0.963). When they were re-evaluated blindly using ESI, there was $74.35 \%$ agreement between observations (Kappa value was 0.646 ). When all patients evaluated by the first emergency physician according to HETS were re-evaluated blindly by the second emergency physician according to ESI, there was $74.67 \%$ agreement between observations (Kappa was 0.652).

When analyzing the agreement between observers in application of HETS in our study, a very good agreement was detected between the first emergency physician, emergency resident, emergency nurse and the second emergency physician applying HETSBlind (Kappa $=1.0$ ); a very good agreement was also detected between intern doctor, non-medical emergency secretary and paramedic (Kappa levels were 0.971, 0.935 and 0.864 , respectively).

Our study showed that the best emergency triage could be applied by emergency physician, emergency resident and emergency nurse who were serving on the subject of emergency medical diseases; a developed and simplified triage system suitable for countries and hospitals according to their patient profiles could be correctly applied even by a non-medical secretary.

The biggest problem in evaluation of emergency triage is to evaluate life-threatening critical or emergent patients as less urgent or non-urgent patients.

These incorrectly undertriaged patients could be kept waiting in incorrect areas of emergency departments for a long time; thus the mortality and morbidity ratios could be increased.

Another problem is to evaluate less urgent or nonurgent patients as emergent or urgent patients. These incorrectly overtriaged patients could unnecessarily occupy emergency departments and emergency department staff and could cause the real urgent patients to be overlooked.

In some of the studies, incorrect overtriage ratios were reported as between 16-62\% and incorrect undertriage ratio was reported as $16-61 \% .^{[49-51]}$

In our study, incorrect overtriage ratio was found as $7.25 \%$ and incorrect undertriage ratio was found as $1.08 \%$ in evaluation of all patients.

There were no life-threatening cases in the patients with incorrect undertriage ratio. The difference in $\mathrm{T} 1$ triage evaluations between HETS and ESI caused the incorrect overtriage of 22 patients. While life-threat- 
ening cases such as arrest appeared in Triage 1 category of ESI, all unstable patients appeared in Triage 1 category of HETS.

Complaint-based 5-level Hacettepe Emergency Triage System developed for overcrowded emergency departments is a triage system which has "a very good agreement" between observations and observers, low undertriage and overtriage ratios, and easy application by all staff from the non-medical secretary to the emergency physician.

Conflict-of-interest issues regarding the authorship or article: None declared.

\section{REFERENCES}

1. Barrett L, Ford S, Ward-Smith P. A bed management strategy for overcrowding in the emergency department. Nurs Econ 2012;30:82-5, 116.

2. Geelhoed GC, de Klerk NH. Emergency department overcrowding, mortality and the 4-hour rule in Western Australia. Med J Aust 2012;196:122-6.

3. Hoot NR, Aronsky D. Systematic review of emergency department crowding: causes, effects, and solutions. Ann Emerg Med 2008;52:126-36.

4. Shetty A, Gunja N, Byth K, Vukasovic M. Senior Streaming Assessment Further Evaluation after Triage zone: a novel model of care encompassing various emergency department throughput measures. Emerg Med Australas 2012;24:374-82.

5. Richards JR, Ozery G, Notash M, Sokolove PE, Derlet RW, Panacek EA. Patients prefer boarding in inpatient hallways: correlation with the national emergency department overcrowding score. Emerg Med Int 2011;2011:840459.

6. Jones PG, Olsen S. Point prevalence of access block and overcrowding in New Zealand emergency departments in 2010 and their relationship to the 'Shorter Stays in ED' target. Emerg Med Australas 2011;23:587-92.

7. Ardagh MW, Tonkin G, Possenniskie C. Improving acute patient flow and resolving emergency department overcrowding in New Zealand hospitals--the major challenges and the promising initiatives. N Z Med J 2011;124:64-73.

8. Oredsson S, Jonsson H, Rognes J, Lind L, Göransson KE, Ehrenberg A, et al. A systematic review of triage-related interventions to improve patient flow in emergency departments. Scand J Trauma Resusc Emerg Med 2011;19:43.

9. Rowe BH, Villa-Roel C, Guo X, Bullard MJ, Ospina M, Vandermeer $\mathrm{B}$, et al. The role of triage nurse ordering on mitigating overcrowding in emergency departments: a systematic review. Acad Emerg Med 2011;18:1349-57.

10. Aacharya RP, Gastmans C, Denier Y. Emergency department triage: an ethical analysis. BMC Emerg Med 2011;11:16.

11. Moskop JC, Sklar DP, Geiderman JM, Schears RM, Bookman KJ. Emergency department crowding, part 1-concept, causes, and moral consequences. Ann Emerg Med 2009;53:605-11.

12. Trout A, Magnusson AR, Hedges JR. Patient satisfaction investigations and the emergency department: what does the literature say? Acad Emerg Med 2000;7:695-709.

13. Derlet RW, Richards JR. Overcrowding in the nation's emergency departments: complex causes and disturbing effects. Ann Emerg Med 2000;35:63-8.

14. Schiff GD. System dynamics and dysfunctionalities: levers for overcoming emergency department overcrowding. Acad
Emerg Med 2011;18:1255-61.

15. Wuerz R, Fernandes CM, Alarcon J. Inconsistency of emergency department triage. Emergency Department Operations Research Working Group. Ann Emerg Med 1998;32:431-5.

16. Travers DA, Waller AE, Bowling JM, Flowers D, Tintinalli J. Five-level triage system more effective than three-level in tertiary emergency department. J Emerg Nurs 2002;28:395400.

17. Beveridge R, Ducharme J, Janes L, Beaulieu S, Walter S. Reliability of the Canadian emergency department triage and acuity scale: interrater agreement. Ann Emerg Med 1999;34:155-9.

18. Parenti N, Manfredi R, Bacchi Reggiani ML, Sangiorgi D, Lenzi T. Reliability and validity of an Italian four-level emergency triage system. Emerg Med J 2010;27:495-8.

19. Parenti N, Ferrara L, Bacchi Reggiani ML, Sangiorgi D, Lenzi T. Reliability and validity of two four-level emergency triage systems. Eur J Emerg Med 2009;16:115-20.

20. McHugh M, Tanabe P, McClelland M, Khare RK. More patients are triaged using the Emergency Severity Index than any other triage acuity system in the United States. Acad Emerg Med 2012;19:106-9.

21. Howlett MK, Atkinson PR. A method for reviewing the accuracy and reliability of a five-level triage process (canadian triage and acuity scale) in a community emergency department setting: building the crowding measurement infrastructure. Emerg Med Int 2012;2012:636045.

22. T.C. Sağlık Bakanlığı. Renk Kodlaması ve Triyaj Uygulaması. Yataklı Sağlık Tesislerinde Acil Servis Hizmetlerinin Uygulama Usul Ve Esasları Hakkında Tebliğ. 2009 Resmi Gazete, Say1: 27378.

23. Australasian College for Emergency Medicine. The Australasian Triage Scale (ATS). http://www.acem.org.au/media/ policies_and_guidelines/G24_Implementation_ATS. pdf (accessed April 2012).

24. Canadian Association of Emergency Physicians. The Canadian Triage \& Acuity Scale (CTAS) for emergency departments. http://caep.ca/resources/ctas\#guidelines (accessed April 2012).

25. Cooke MW, Jinks S. Does the Manchester triage system detect the critically ill? J Accid Emerg Med 1999;16:179-81.

26.Zimmermann PG. The case for a universal, valid, reliable 5-tier triage acuity scale for US emergency departments. J Emerg Nurs 2001;27:246-54.

27. Wuerz RC, Milne LW, Eitel DR, Travers D, Gilboy N. Reliability and validity of a new five-level triage instrument. Acad Emerg Med 2000;7:236-42.

28. Wuerz RC, Travers D, Gilboy N, Eitel DR, Rosenau A, Yazhari R. Implementation and refinement of the emergency severity index. Acad Emerg Med 2001;8:170-6.

29. Toulson K, Laskowski-Jones L, McConnell LA. Implementation of the five-level emergency severity index in a level I trauma center emergency department with a three-tiered triage scheme. J Emerg Nurs 2005;31:259-64.

30. Gurney D. Comparing triage decisions for the same patients with a five-level and a three-level triage scale: a quick exercise for nurses orienting to triage. J Emerg Nurs 2003;29:191-2.

31. Travers DA, Waller AE, Bowling JM, Flowers D, Tintinalli J. Five-level triage system more effective than three-level in tertiary emergency department. J Emerg Nurs 2002;28:395400 .

32. Tanabe P, Gimbel R, Yarnold PR, Kyriacou DN, Adams JG. Reliability and validity of scores on The Emergency Severity Index version 3. Acad Emerg Med 2004;11:59-65. 
33. Storm-Versloot MN, Ubbink DT, Kappelhof J, Luitse JS. Comparison of an informally structured triage system, the emergency severity index, and the manchester triage system to distinguish patient priority in the emergency department. Acad Emerg Med 2011;18:822-9.

34. Beveridge R, Ducharme J, Janes L, Beaulieu S, Walter S. Reliability of the Canadian emergency department triage and acuity scale: interrater agreement. Ann Emerg Med 1999;34:155-9.

35. Jelinek GA, Little M. Inter-rater reliability of the National Triage Scale of 11,500 simulated occasions of triage. Emerg Med 1996;8:226-30.

36. Worster A, Fernandes CM, Eva K, Upadhye S. Predictive validity comparison of two five-level triage acuity scales. Eur J Emerg Med 2007;14:188-92.

37. Worster A, Gilboy N, Fernandes CM, Eitel D, Eva K, Geisler $\mathrm{R}$, et al. Assessment of inter-observer reliability of two fivelevel triage and acuity scales: a randomized controlled trial. CJEM 2004;6:240-5.

38. Gilboy N, Travers D, Wuerz R. Re-evaluating triage in the new millennium: A comprehensive look at the need for standardization and quality. J Emerg Nurs 1999;25:468-73.

39. Wuerz RC, Milne LW, Eitel DR, Travers D, Gilboy N. Reliability and validity of a new five-level triage instrument. Acad Emerg Med 2000;7:236-42.

40. Choi YF, Wong TW, Lau CC. Triage rapid initial assessment by doctor (TRIAD) improves waiting time and processing time of the emergency department. Emerg Med J 2006;23:262-5.

41. Durand AC, Gentile S, Gerbeaux P, Alazia M, Kiegel P, Luigi $\mathrm{S}$, et al. Be careful with triage in emergency departments: interobserver agreement on 1,578 patients in France. BMC Emerg Med 2011;11:19.

42. Johansen MB, Forberg JL. Nurses' evaluation of a new for- malized triage system in the emergency department - a qualitative study. Dan Med Bull 2011;58:A4311.

43. Burström L, Nordberg M, Ornung G, Castrén M, Wiklund T, Engström ML, et al. Physician-led team triage based on lean principles may be superior for efficiency and quality? A comparison of three emergency departments with different triage models. Scand J Trauma Resusc Emerg Med 2012;20:57.

44. Rowe BH, Villa-Roel C, Guo X, Bullard MJ, Ospina M, Vandermeer $\mathrm{B}$, et al. The role of triage nurse ordering on mitigating overcrowding in emergency departments: a systematic review. Acad Emerg Med 2011;18:1349-57.

45. Kahveci FO, Demircan A, Keles A, Bildik F, Aygencel SG. Efficacy of triage by paramedics: a real-time comparison study. J Emerg Nurs 2012;38:344-9.

46. Storm-Versloot MN, Ubbink DT, Chin a Choi V, Luitse JS. Observer agreement of the Manchester Triage System and the Emergency Severity Index: a simulation study. Emerg Med J 2009;26:556-60.

47. Chi CH, Huang CM. Comparison of the Emergency Severity Index (ESI) and the Taiwan Triage System in predicting resource utilization. J Formos Med Assoc 2006;105:617-25.

48. Buschhorn HM, Strout TD, Sholl JM, Baumann MR. Emergency Medical Services Triage Using the Emergency Severity Index: Is it Reliable and Valid? J Emerg Nurs 2012 Jan 12.

49. Pointer JE, Levitt MA, Young JC, Promes SB, Messana BJ, Adèr ME. Can paramedics using guidelines accurately triage patients? Ann Emerg Med 2001;38:268-77.

50. Asplin BR. Undertriage, overtriage, or no triage? In search of the unnecessary emergency department visit. Ann Emerg Med 2001;38:282-5.

51. Boyle MJ. Is mechanism of injury alone in the prehospital setting a predictor of major trauma - a review of the literature. J Trauma Manag Outcomes 2007;1:4. 